University for Business and Technology in Kosovo

UBT Knowledge Center

Theses and Dissertations

Student Work

Fall 9-2019

\title{
Cilësia dhe vlerat ushqyese të ushqimit për foshnja
}

Diellza Azemi

University for Business and Technology - UBT

Follow this and additional works at: https://knowledgecenter.ubt-uni.net/etd

Part of the Food Science Commons

\section{Recommended Citation}

Azemi, Diellza, "Cilësia dhe vlerat ushqyese të ushqimit për foshnja" (2019). Theses and Dissertations. 8. https://knowledgecenter.ubt-uni.net/etd/8

This Thesis is brought to you for free and open access by the Student Work at UBT Knowledge Center. It has been accepted for inclusion in Theses and Dissertations by an authorized administrator of UBT Knowledge Center. For more information, please contact knowledge.center@ubt-uni.net. 


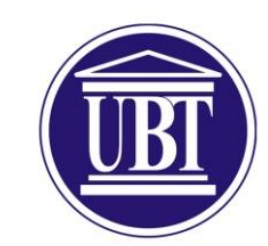

Kolegji UBT

Fakulteti: Shkencat e Ushqimit dhe Bioteknologji

Specializimi: Menaxhimi me Cilësinë dhe Sigurinë ushqimore

\section{CILËSIA DHE VLERAT USHQYESE TË USHQIMIT PËR FOSHNJA}

Shkalla Bachelor

Diellza Azemi

Shtator / 2019

Prishtinë 


\title{
UBI
}

Kolegji UBT

Fakulteti:Shkencat e Ushqimit dhe Bioteknologji

Specializimi: Specializimi: Menaxhimi me Cilësinë dhe Sigurinë ushqimore

Punim Diplome

Viti akademik 2016-2017

Diellza Azemi

\section{CILËSIA DHE VLERAT USHQYESE TË USHQIMIT PËR FOSHNJA}

\author{
Mentori: Dr.sc.Hyrie Koraqi
}

Shtator / 2019

Ky punim është përpiluar dhe dorëzuar në përmbushjen e kërkesave të pjesshme për Shkallën Bachelor 


\begin{abstract}
ABSTRAKT
Ushqimi komercial për fëmijë perfshinë ato produkte që bëhen zakonisht me drithëra,fruta dhe perime,sheqer dhe aditivë të ndryshëm. Ashtu si produktet ushqimore të destinuara për përdorime të veçanta ushqyese, ushqimet për fëmijë dhe për foshnja kërkojnë seri udhëzimesh të rrepta si cilësia dhe siguria ushqyese, shtimi dhe kontrollimi i aditivëve dhe etiketimi. Sidoqoftë, duke qenë një shtesë e rëndësishme për dietën e foshnjave dhe fëmijëve dhe për përshtatjen e tyre me ushqimin e zakonshëm, cilësinë ushqyese e ushqimit komercial për foshnja dhe fëmijë të bazuar në drithëra,fruta dhe perime ka rendesi shumë të madhe. Shembuj të ushqimit komercial për foshnja dhe fëmijë nga tregu dhe farmacitë $u$ analizuan nga parametrat: $\mathrm{pH}$, materie e thatë e tretshme, lagështi, aciditet total, vitaminë $\mathrm{C}$, proteina, sheqerna dhe lipide. Të gjitha mostrat e ushqimit për foshnja dhe fëmijë prodhohen nga kompani të huaja pasi aktualisht nuk ka prodhues të Kosovës që prodhojnë këtë gamë të produkteve. Parametrat e cilësisë ushqyese janë të rëndësishme për të vlerësuar cilësinë e produktit dhe si mund të ruhet në mënyrë të sigurt. Parametrat e analizuar ishin të gjitha brenda kufijve të lejuar. Sidoqoftë, si një masë paraprake, vërejtjet për përmbajtjen në etiketat e produkteve duhet të ndiqen gjithmonë.
\end{abstract}




\section{MIRËNJOHJE/FALENDERIME}

Në përfundim te kësaj pune hulumtuese shkencore, kam kënaqësi të falenderoj të gjithë stafin e UBT-s të angazhuar në punimin tim. Falenderoj Depamentin e Shkencave te Ushqimit dhe Bioteknologjise që mundesoi të shfrytëzoj laboratoret dhe paisjet e nevojshme. Respekt dhe mirënjohje për secilin prej tyre për sugjerimet dhe vërejtjet që më kanë bërë gjatë kësaj periudhe.

Falenderim $i$ vecante shkon për mentoren time,Dr.sc. Hyrie Koraqi e cila edhe pse kishte angazhimet e saj, mori përsipër të më udhëheqё, të më mbështesë dhe ndihmojë në zhvillimin e kësaj teme.E vlersoj sugjerimin qe më dha për temë dhe profesionalizimin e saj në realizimin e pjesës eksperimentale.Mbi të gjitha falendroj për keshillat,durimin dhe orientimin e dhënë.

Me shumë respekt falenderoj kolegen time Sara Selimi, ku mbeshtetja dhe inkurajimi nga ana e saj nuk kanë munguar asnjeherë. Jo vetëm gjatë kësaj periudhe por gjatë gjithë këtyre viteve studimi.

Dhe së fundi, por jo më pak e rendesishme, një falenderim $i$ shkon familjes sime për mbeshtetjen e vazhdueshme gjatë gjithë kohës.Pa ta me të vërtetë nuk do te isha këtu ku jam. 


\section{PËRMBAJTJA}

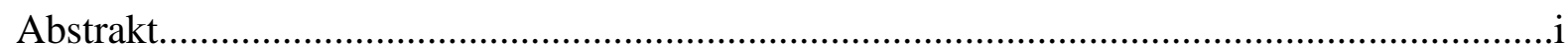

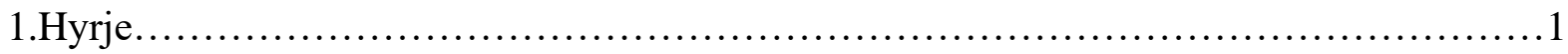

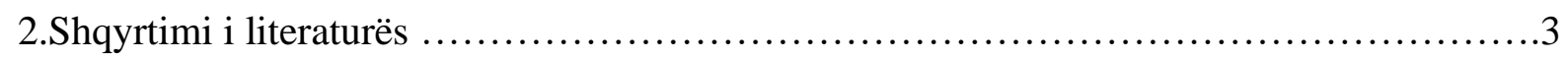

2.1. Ushqimet plotsuese me bazë drithërash dhe frutash................................... 3

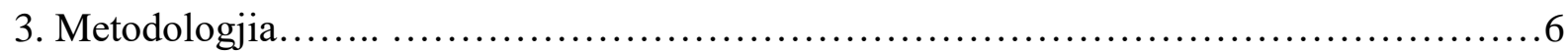

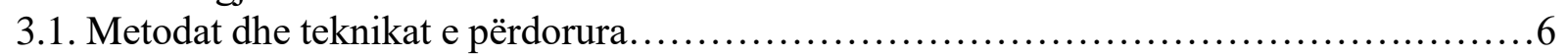

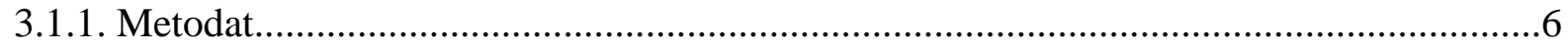

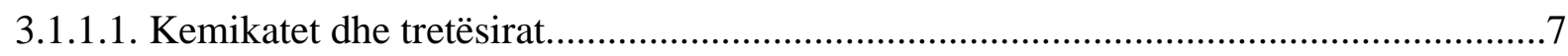

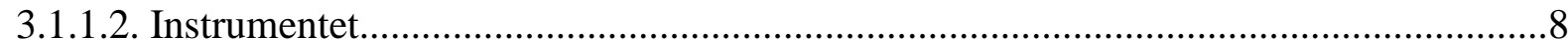

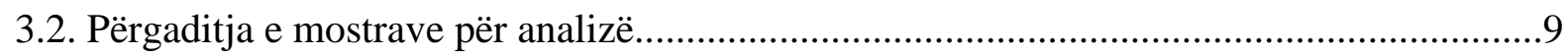

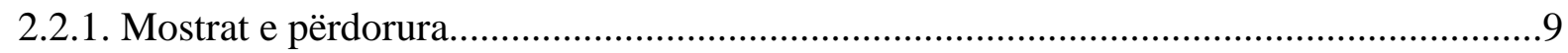

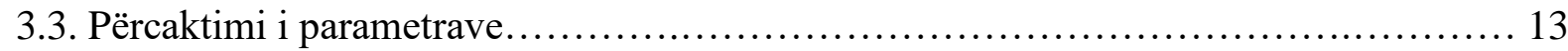

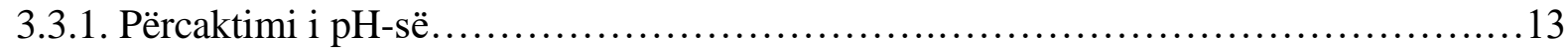

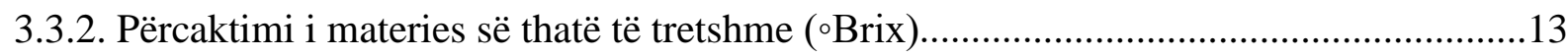

3.3.3.Përcaktimi i lagështisë.Metoda me tharje në furrë në $105^{\circ} \mathrm{C}$.............................................13

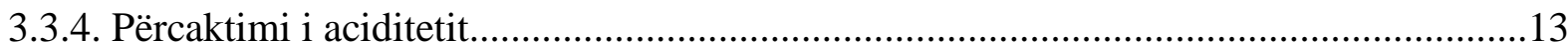

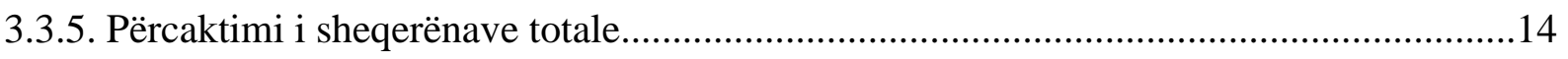

3.3.6. Përcaktimi i sheqerënave të reduktuara......................................................................14

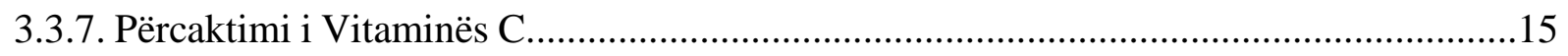

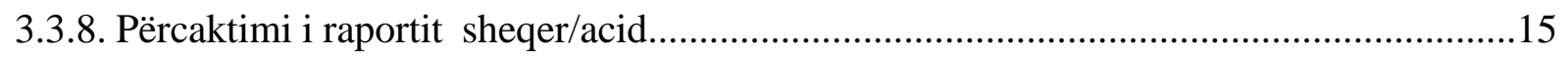

3.3.9. Përcaktimi i proteinave

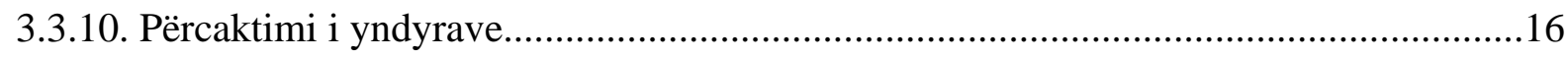

4. Analizat statistikore

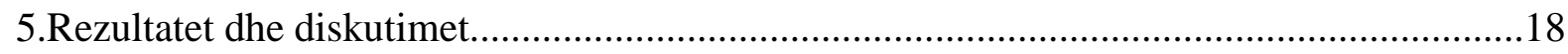




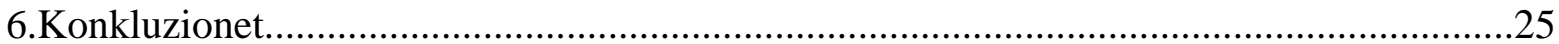

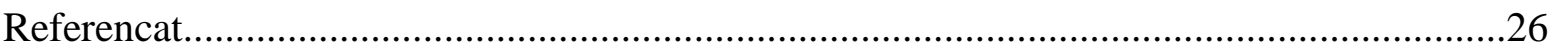




\section{LISTA E FIGURAVE}

Figura 1. Pure dridhërash dhe frutash të kompanive të ndryshme..........................................5

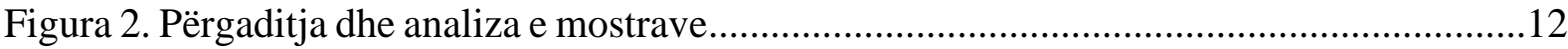

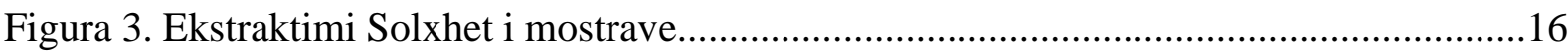

Figura 4. Drejtëza kalibruese e acidit askorbik (vitamina C) ...........................................23

Figura 5. Drejtëza kalibruese e proteinës (xhelatinë).....................................................23

Figura 6. Drejtëza kalibruese e sheqerit (glukozë)..............................................................24

Figura 7. Vizualizimi 3D i të dhënave nga parametrat kimik dhe nutricional të ushqimeve për

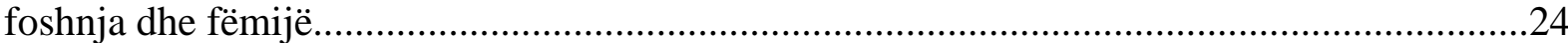




\section{LISTA E TABELAVE}

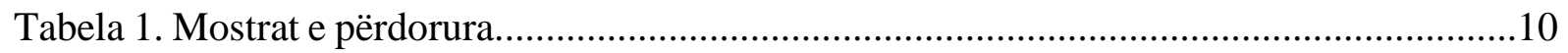

Tabela 2. Përberja kimike e ushqimit për foshnja dhe fëmijë me bazë drithërat.....................18

Tabela 3. Vlerat nutricionale të ushqimit për foshnja dhe fëmijë me bazë drithërat................18

Tabela 4. Përberja kimike e ushqimit për foshnja dhe fëmijë me bazë fruta..........................20

Tabela 5. Vlerat nutricionale të ushqimit për foshnja dhe fëmijë me bazë fruta....................20 


\section{HYRJE}

Ushqimet plotsuese komerciale për foshnje dhe fëmijë me bazë drithëra dhe fruta janë produktet që përgaditen zakonisht nga drithërat, frutat, sheqer dhe aditivë të ndryshëm. Si ushqime të destinuara për përdorime të vecanta ushqyese, ushqimet për foshnja dhe fëmijë duhet të përputhen me një seri udhëzimesh të rrepta p.sh. cilësia ushqyese, shtimi i aditivëve, etiketimi. Foshnjat midis moshës 6 muaj dhe 3 vjeç janë mjaftë të kufizuara në zgjedhjet e tyrë të ushqimit, ushqimet komerciale për foshnje dhe fëmijë shërbejnë si burim i rëndesishëm i energjisë, lëndëve ushqyese themelore, fibra, vitamina dhe minerale (Čížková et al.2009). Ushqimet për foshnja dhe fëmijë me bazë drithërat luajnë një rol të rëndësishëm në periudhën plotësuese të ushqyerjes. Ato përfshijnë misër, thekër, grurë, oriz, elb, tërshërë etj. Drithërat e foshnjës përcaktohen si "ushqime bazë të përpunuara të bazuara në drithëra që ndahen në: drithëra të thjeshta ose ato që duhet të pergaditen me qumësht ose lëngje të tjera ushqyese të përshtatshme". Në shumë vende, drithërat për foshnje janë ushqimet e para që prezantohen në fillim të periudhës plotësuese të ushqyerjes. Drithërat janë një burim i shkëlqyeshëm i energjisë, që është shumë e rëndësishme në moshën gjashtë muajshe, kur ekskluzivisht ushqyerja me gji nuk është më e mjaftueshme për të mbuluar kërkesat ushqyese të foshnjës. Për më tepër, drithërat sigurojnë një sasi të konsiderueshme të karbohidrateve dhe proteinave, por janë gjithashtu një burim i vitaminave, mineraleve dhe komponimeve bioative (Klerks et al.2019).

Poashtu, ushqimet për foshnja dhe fëmijë me bazë frutash luajnë një rol të rëndësishëm në periudhën plotësuese të ushqyerjes. Ato përfshijnë pure frutash dhe perimesh si: banane, fruta mali dhe mollë, kumbullë, mollë dhe banane, dardhë, fruta dhe perime si: karrotë dhe mollë etj.Për më tepër, frutat dhe perimet sigurojnë një sasi të konsiderueshme të karbohidrateve dhe vitaminave, por janë gjithashtu edhe burim i mineraleve dhe komponimeve bioaktive.

Gjatë mbijetesës dhe zhvillimit të njeriut ndër vite të ushqyerit ka qenë gjithnjë një nga problemet themelore.Burimi i energjisë dhe i mikroelementeve të domosdoshme për rritje dhe zhvillim të organizmit vjen nga ushqimi.Organizmi ynë ka nevojë për shumëllojshmeri nutrientësh energjetik si: karbohidrate, lipide, proteina dhe fibra, si dhe jo energjetik vitamina, kripëra minerale dhe ujë.

Rendësi mjaftë të madhe paraqet siguria e çdo produkti ushqimor. Me siguri ushqimore nënkuptohet mbrojtja e shëndetit të konsumatorëve nga rreziqet të cilat mund të vijnë nga ndryshimet negative fizike,kimike dhe mikrobiologjike.Konsumimi i një ushqimi të kontaminuar me mikroorganizma patogjen dhe prania e substancave kimike ose toksike shkaktojnë infeksionet që kanë origjinë ushqimin si dhe helmimet ushqimore.

Faktorët që ndikojnë në zgjedhjen e ushqimeve nga ana e konsumatorëve janë faktorët: ekonomik,social,demografik. Foshnjet dhe fëmijët e vegjël janë popullësi veçanarisht e ndjeshme ndaj ekspozimit të produkteve që ata konsumojnë si dhe ndaj ndotësve të mjedisit. Kadmiumi dhe arseniku janë elemente që kontribuojne për efektet shendetsore të foshnjës apo femijës, si kanceri dhe te sëmundjet neurologjike. Edhe pse metale të renda mund të permbajnë ushqimet për femijë dhe lengjet që vijnë nga frutat e rritura në tokën e kontaminuar ose të ekspozuar ndaj ndotjes gjatë procesit të prodhimit, mirpo nuk ka udhezime për nivelet që 
konsiderohen të jenë te sigurta.Kemi raste kur produktet ushqimore per fëmijë kanë qenë të lidhura me sëmundje serioze dhe vdekje të foshnjave, e gjitha kjo për shkak të infeksioneve mikrobike.

Frutat, frutat e thata, produktet e qumështit, drithërat janë nga disa ushqimet që përdoren për formulimin e ushqimit plotsues për foshnje dhe femijë të vegjël. Mykotoksinat dhe përmbajtja mykore që prodhohen nga disa gjini te myshqeve, veçanërisht nga Penecillium, Aspergillius, njihen si problem që përfshinë gjithë botën e në vecanti vendet me klimë tropikale ku temperatura është më e lartë dhe ka lagështi relative tipike të kësaj klime.

Në shumë ushqime të përpunuara dhe të papërpunuara mund të jenë të pranishëm karcinogjenet. Ku drithërat dhe qumështi janë produktet më të ndjeshme ndaj ndotjës me mykotoksina dhe që perdoren shpesh si përbërës në shumë produkte ushqimore për foshnja dhe fëmijë (Dhamo, 2014). 


\section{SHQYRTIMI I LITERATURËS}

\subsection{USHQIMET PLOTSUESE ME BAZË DRITHËRASH DHE FRUTASH}

Përgjithësisht, pasi foshnja ka mbushur 6 muaj përveç ushqyerjes me gji ose formula të ndryshme të qumështit duhet të ushqehet edhe me produkte të tjera, pra foshnja duhet të ushqehet me ushqimet plotsuese të cilat janë kryesisht formë pureje me bazë drithrash, frutash e perimesh.Ka mendime të ndryshme rreth moshës në muaj kur duhet të fillohen ushqimet plotsuese, disa pediatër këshillojnë muajin e gjashtë por ka edhe mjaft të tjerë që i rekomandojnë ushqimin plotsues që në muajin e katërt.

Foshnja është gati për të filluar ushqimet plotsuese kur:

$>$ arrin t’a mbajë kokën e tij në pozicionin vertikal (ka kontroll të kokës së tij).

$>$ mund të ulet dhe të ruajë qëndrimin.

$>$ fillon të fusë në gojë lodrat e tij dhe objekte të tjera.

$>$ shfaq kuriozitet për atë se çfarë konsumojnë të rriturit.

$>$ e hap gojën me lehtësi kur nëna i afron lugën me ushqim.

$>$ Foshnja është i aftë të përtypë dhe jo vetëm të thithë.

Tentativat e para për të ushqyer foshnjen mund të jenë të avashta dhe jo fortë të këndshme. Ushqimi foshnjes ndihmon në fillimin e daljes së dhëmbëve, të folurit dhe të rriturit e shëndetshëm. Disa nga ushqimet qe mund të fillojnë janë:

1. Drithërat: miell i orizit është zgjedhja e parë për shumicën e prindërve. Përgatesa në formë pureje ose qulli përgatitet me ujë ose qumësht dhe konsistenca varet sipas foshnjës. Shërbehet me lugë dhe gradualisht ulet sasia e ujit/qumshtit që shtohet për përgatitje me rritjen e foshnjës.

2. Puretë e frutave dhe perimeve: pasi foshnja fillon dhe i konsumon gjithmonë e më tepër miellrat, ky është momenti i duhur për të filluar me puretë e perimeve dhe frutave. Në fillim puretë duhet të pergatiten nga një përberës i vetëm dhe të pritet nga 3-5 ditë para se të ofrohet një pure e re. Nëse foshnja ka reaksion alergjik që shfaqet me diare, të vjella, skuqje, pureja duhet të nderpritet. Pas disa kohësh foshnja mund të ushqehet me pure të përbëra nga disa përbërsë.

Nevoja ditore e foshnjës për pure frutash ose perimesh është 25-40 gram.Së pari foshnja ushqehet me pure perimesh dhe më pas fillohet pureja e frutave (pure molle, dardhe, kumbulle,banana). Pasi është ushqyer me pure të përgatitura vetëm me një përbërës, foshnja ushqehet me pure të përgatitura me më shumë përbërs.Të tilla janë: pure mollëpjeshkë, mollë-dardhë, karrotë,mollë,pjeshkë. Frutat dhe perimet që duhet të shmangen 
për t'u bërë pure janë: pangjari, rrepa, spinaqi dhe lakra. Në këto perime niveli i nitrateve është i lartë dhe kjo mund të shkaktojë anemi, ulje të rruazave të kuqe të gjakut për bebet e vogla.Pasi ushqyerjes me këto pure mund të fillohet me pure të tjera të kombinuara midis perimeve dhe mishit ose vetëm puresë së mishit të përbërë nga një lloj i vetëm mishi ose 2 llojesh.

Puretë mund të jenë:

$>$ Pure e homogjenizuar plotesisht.

$>$ Pure e shtypur fortë dhe jo tërësisht e homogjenizuar (si qull,7-9 muajsh).

$>$ Pure e shtypur e cila përmbanë edhe copëza (8-10muajsh).

3. Ushqimet e prera ose "finger foods" kur foshnja arrin 8-10 muajsh ose më shumë, është i aftë të mbaje porcione të vogla ushqimi në dorë. Me rritjen e fëmijës, ushqimi bëhet gradualisht i njejtë për të gjithë familjen (Ceta et al.2017). 

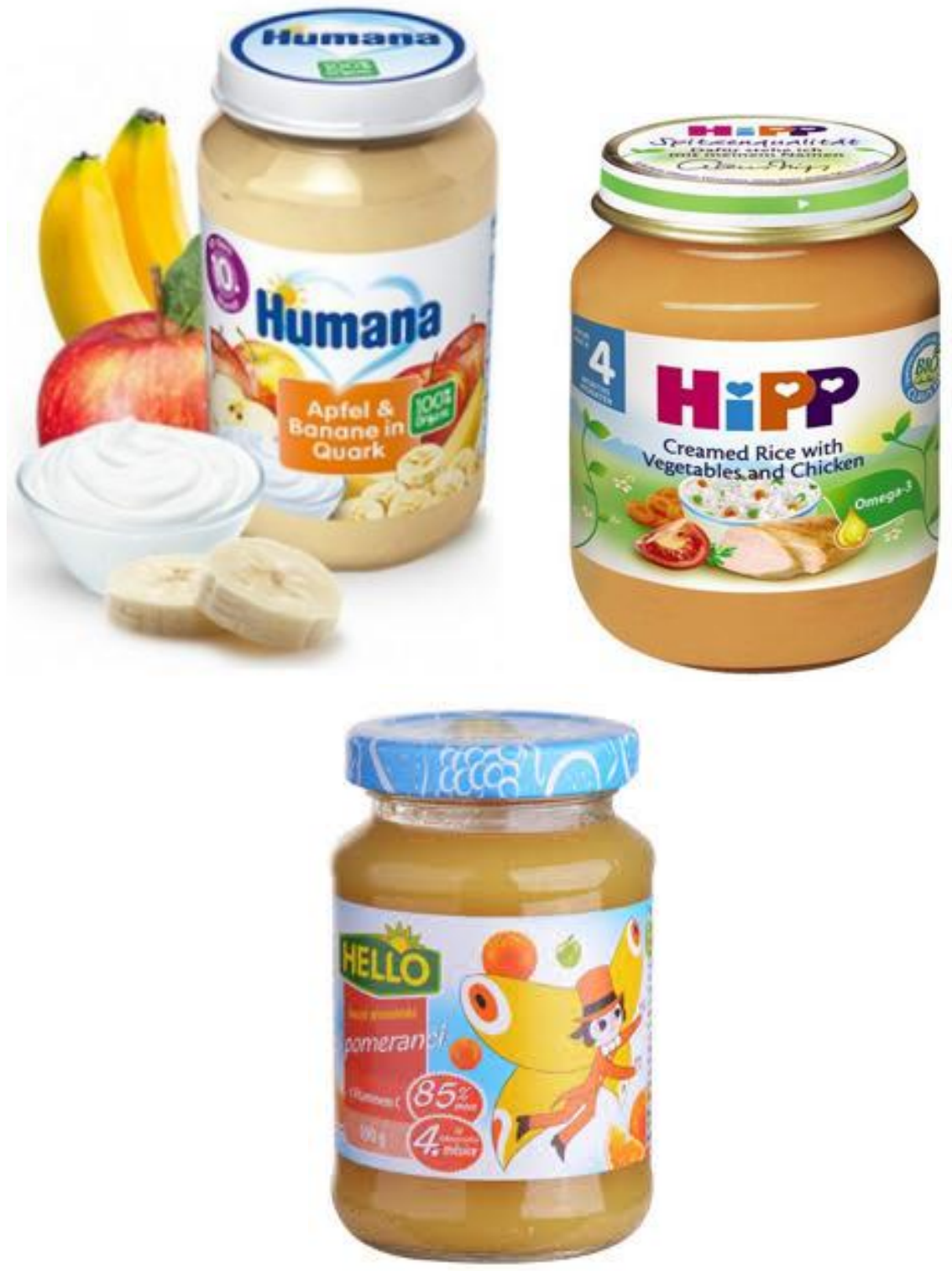

Figura 1. Pure dridhërash dhe frutash të kompanive të ndryshme 


\section{PJESA EKSPERIMENTALE}

\section{METODOLOGJIA}

\subsection{METODAT DHE TEKNIKAT E PËRDORURA}

Mostrat e ushqimit plotsues komercial për foshnje dhe fëmijë me bazë drithëra dhe me bazë fruta me emrin tregtar HUMANA (produkt me bazë misri), HiPP (produkt me bazë orizi), FRUTEK (Banane, produkt me bazë fruta), HiPP (Fruta mali në mollë, kumbull,mollë me banane, produkte me bazë fruta) dhe HELLO (Karrotë dhe mollë e gjelbërt, produkt me bazë fruta-perime) janë blerë në markete dhe barnatore në Kosovë gjatë periudhës qershor 2019 dhe janë analizuar të gjitha 8 mostrat. Përcaktimi i vlerave ushqyese dhe cilësisë së ushqimit për foshnja dhe fëmijë është analizuar përmes parametrave kimikë dhe nutricional si: $\mathrm{pH}$, materia e thatë e tretshme ( ${ }^{\circ}$ Brix), lagështia, aciditeti total, Vitamina $C$, sheqernat totale, sheqernat e reduktuara, saharoza, proteinat dhe yndyrat. Parametrat e lartëcekura tregojnë për cilësinë e dhe vlerat ushqyese të foshnjave dhe fëmijëve dhe përmbajtjen e tyre. Përcaktimi i vlerave ushqyese përmes këtyre parametrave ëshë analizuar sipas metodave standarde të analizës AOAC 2016.

\subsubsection{METODAT}

\section{Spektrofotometria}

Spektrofotometria është metodë e absorbimit, e cila bazohet në hulumtimin e varësisë së absorbancës nga gjatësia valore e rrezës,e cila kalon përmes substancës analizuese.Spektrofotometria,fotometria dhe kolorimetria janë variante të ndryshme të analizës spektrale absorbcionometrike të bazuara në ligjin e Beerit.Ligji i Beerit përshkruan absorbimin karakteristik të tufës së rrezeve rënëse monokromatike dhe paralele në mesin homogjen dhe izotrop.Formulimi përfundimtar i thjeshtuar i ligjit të Beerit matematikisht shprehet:

\section{$\mathrm{A}=\boldsymbol{\varepsilon} \mathbf{x c x b}$}

$\mathrm{Ku}:$

A-paraqet absorbancën,

$\boldsymbol{\varepsilon}$-koeficientin molar të absorbimit,

c-përqendrimin dhe

b-trashësinë e shtresës

Ligji i Beerit, në mënyrë eksplicite,paraqet varësinë lineare në mes absorbancës dhe përqendrimit të molekulave absorbuese në tretësirë.Ky ligj kryesisht vlenë për rrezatim monokromatik.Nëse në tretësirën analizuese përqendrimi ndryshon për shkak të protolizës,dimerizimit,solvatimit,tautomerizmit,etj.atëherë kemi shmangie nga ky 
ligj.Spektrofotometria e absorbimit bazohet në matjen e absorbimit të rreztimit monokromatik në regjionin spektral UV-VIS.Spektrofotometrat UV-VIS janë të paisur me llampën e volframit, të hidrogjenit ose me atë të deuteriumit.Si detektor zakonisht përdoren gypat fotomultiplikator me senzorë përkatës për leximin e A ose \% $\mathrm{T}$.

\subsubsection{Kemikatet dhe tretësirat}

Të gjitha tretësirat e nevojshme, për zhvillimin e analizave të parametrave kimik dhe nutricional të ushqimit për foshnja dhe fëmijë, janë përgaditur nga kemikatet analitikisht të pastra (p.a.) duke i tretur ato në ujë të distiluar.Në punën eksperimentale kemi përdorur këto kemikate (nga prodhues të ndryshëm si: "Alkaloid","Honeywell",,'Sigma" etj.) dhe tretësira :

$>$ Permanganati i kaliumit

$>$ Acidi askorbik

$>$ Hidroksidi natriumit

$>$ Fenolftaleina

$>$ Acidi sulfurik

$>$ Petroleum eter

$>$ Xhelatinë

$>$ Tretësirat e Fehlingut I dhe II

$>$ Fenol

$>$ Glukozë

Të gjitha tretësirat janë përgaditur duke e tretur sasinë e nevojshme të substancës përkatëse dhe me hollimin deri në vëllimin e caktuar me ujë të distiluar.

\subsubsection{INSTRUMENTET}

Gjatë punës eksperimentale kemi përdorur këto instrumente:

$>$ Spektrofotometer UV-VIS Genesys 10S

$>\mathrm{pH}$ metër

$>$ refraktotmetër

> Si mjete ndihmëse kanë shërbyer:

> Peshorja analitike

$>$ Enët matëse (vegeglas)

$>$ Eksikatori me $\mathrm{CaO}$

$>$ Tertore 
$>$ Aparatura komplete për distilimin e ujit

$>$ Enë normale $10 \mathrm{~mL}, 25 \mathrm{~mL}, 50 \mathrm{~mL}, 100 \mathrm{~mL}, 250 \mathrm{~mL}, 500 \mathrm{~mL}$

$>$ Erlenmajera $100 \mathrm{~mL}, 250 \mathrm{~mL}$

$>$ Byreta $50 \mathrm{~mL}$

> Gota laboratorike $50 \mathrm{~mL}, 100 \mathrm{~mL}, 250 \mathrm{~mL}$

$>$ Letër filtruese kualitative dhe kuantitative

\subsection{PËRgATITJA E MOSTRAVE PËR ANALIZË}

Mostrat e ushqimit plotsues komercial për foshnje dhe fëmijë me bazë drithëra dhe me bazë fruta me emrin tregtar HUMANA (produkt me bazë misri), HiPP (produkt me bazë orizi), FRUTEK (Banane, produkt me bazë fruta), HiPP (Fruta mali në mollë, kumbull,mollë me banane, produkte me bazë fruta) dhe HELLO (Karrotë dhe mollë e gjelbërt, produkt me bazë fruta-perime) janë blerë në markete dhe barnatore në Kosovë gjatë periudhës qershor 2019 dhe janë analizuar të gjitha 8 mostrat.

$0.5 \mathrm{~g}$ të secilit produkt u holluan në $10 \mathrm{ml}$ ujë të distiluar të acidifikuar (1\%) dhe u ekstraktuan për 10 minuta. Tretësirat u përqendrua në centrifuge $3000 \mathrm{rpm}$ për 10 minuta.

Pjesa e ngurtë, e ndarë nga pjesa e lëngët, iu nenshtua një hapi të ri të ekstraktimit. Fazat e lëngshme u mblodhen dhe u holluan me ujë të distiluar deri në vëllim perfundimtar prej $10 \mathrm{~mL}$. Të gjithë mostrat janë analizauar nga tri herë.

\subsubsection{MOSTRAT E PËRDORURA}

Për përcaktimin e parametrave kimik dhe nutricional i kemi perzgjedhur dy grupe nga produktet ushqimore plotsuese për foshnja dhe fëmijë:

Grupi i parë: produktet miellore me bazë dritherash. Prej tyre janë marrë dy lloje mostra të ndryshme ku te gjitha prej tyre jane nga marketi të njohura dhe të perdorura nga ana e konsumatorëve si: HUMANA (produkt me bazë misri) dhe HiPP (produkt me bazë orizi), Produktet jane prodhime te kompanive te huaja.Aktualisht në Kosovë nuk ka ndonjë kompani prodhuese të ushqimit për foshnja dhe fëmijë.Të gjitha produktet janë të importuara që mund të blihen në markete, barnatore apo edhe në dyqane të tjera ushqimore për foshnja dhe fëmijë.

Grupi i dytë: produktet në formë pureje me bazë fruta dhe perime si: FRUTEK (Banane, produkt me bazë fruta), HiPP (Fruta mali në mollë, kumbull,mollë me banane, produkte me bazë fruta) dhe HELLO (Karrotë dhe mollë e gjelbërt, produkt me bazë fruta-perime). 
Tabela 1. Mostrat e përdorura

\begin{tabular}{|l|}
\hline Mostrat: \\
\hline A3-HiPP-MOLLË ME FRUTA MALI \\
\hline A4-HiPP- KUMBULL \\
\hline A5-HiPP-MOLLË ME BANANE \\
\hline A6-HiPP-DARDHË \\
\hline A7-FRUTEK-BANANE \\
\hline A8-HELLO-KARROTË DHE MOLLË \\
\hline A2-HiPP-ORIZ \\
\hline A1-HUMANA-MISËR \\
\hline
\end{tabular}




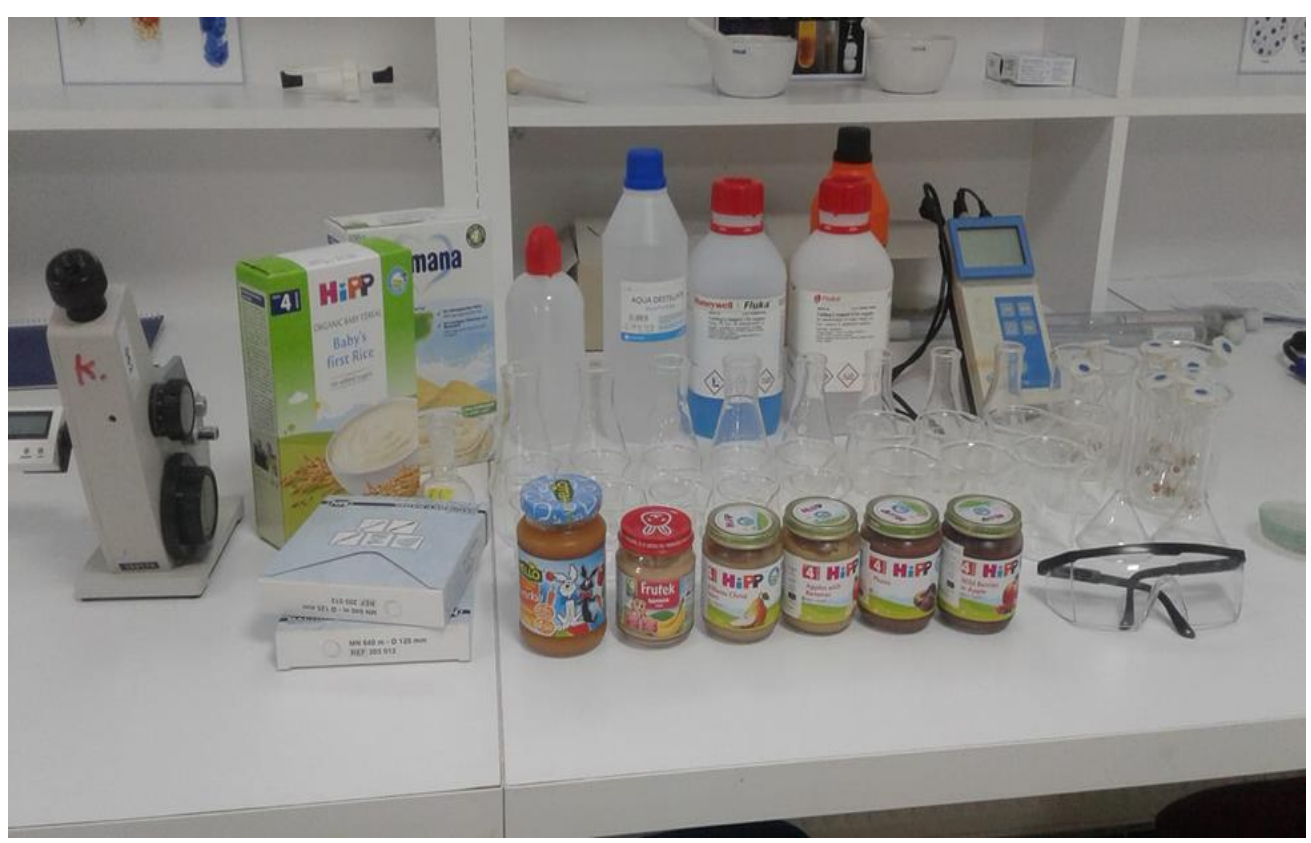




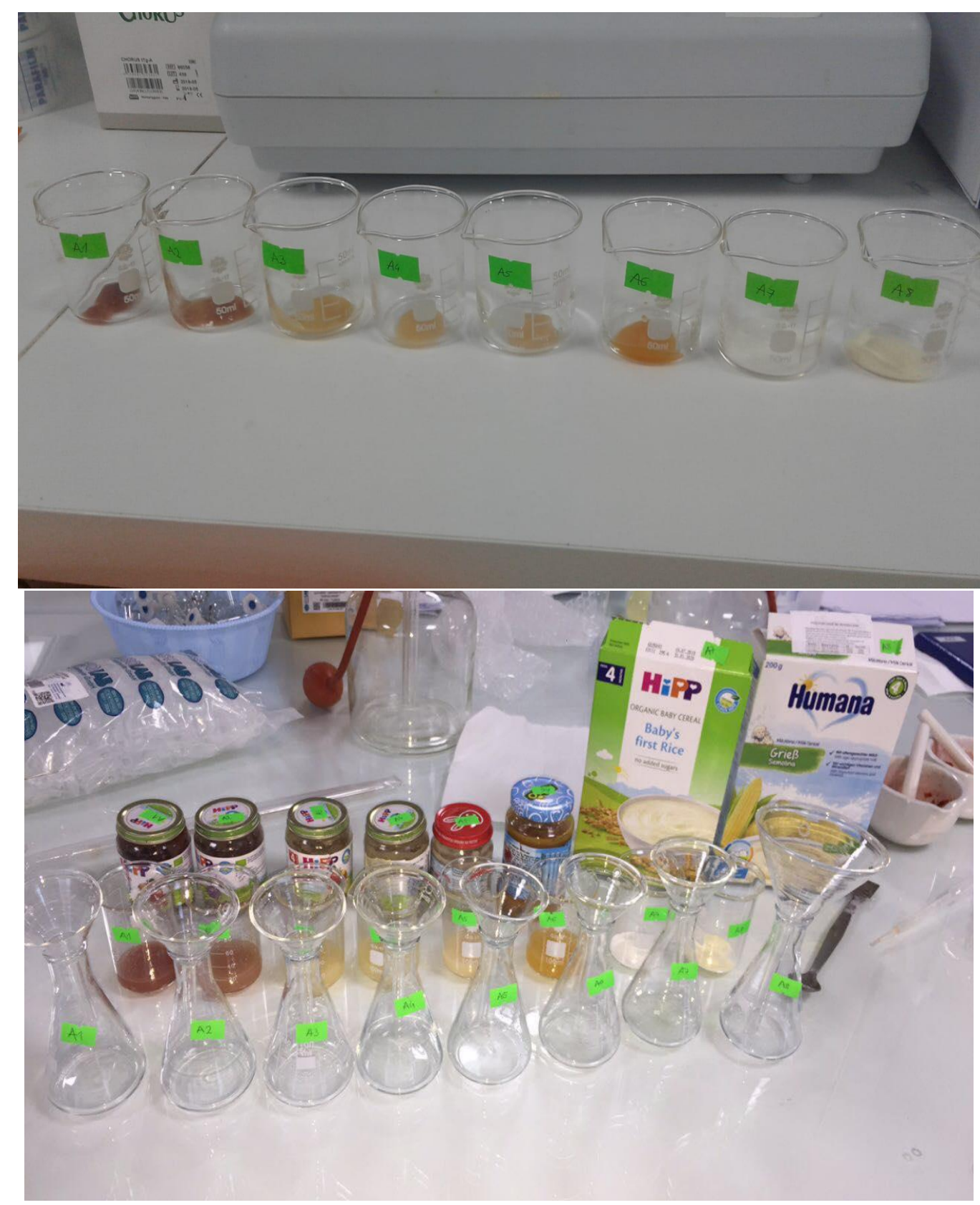




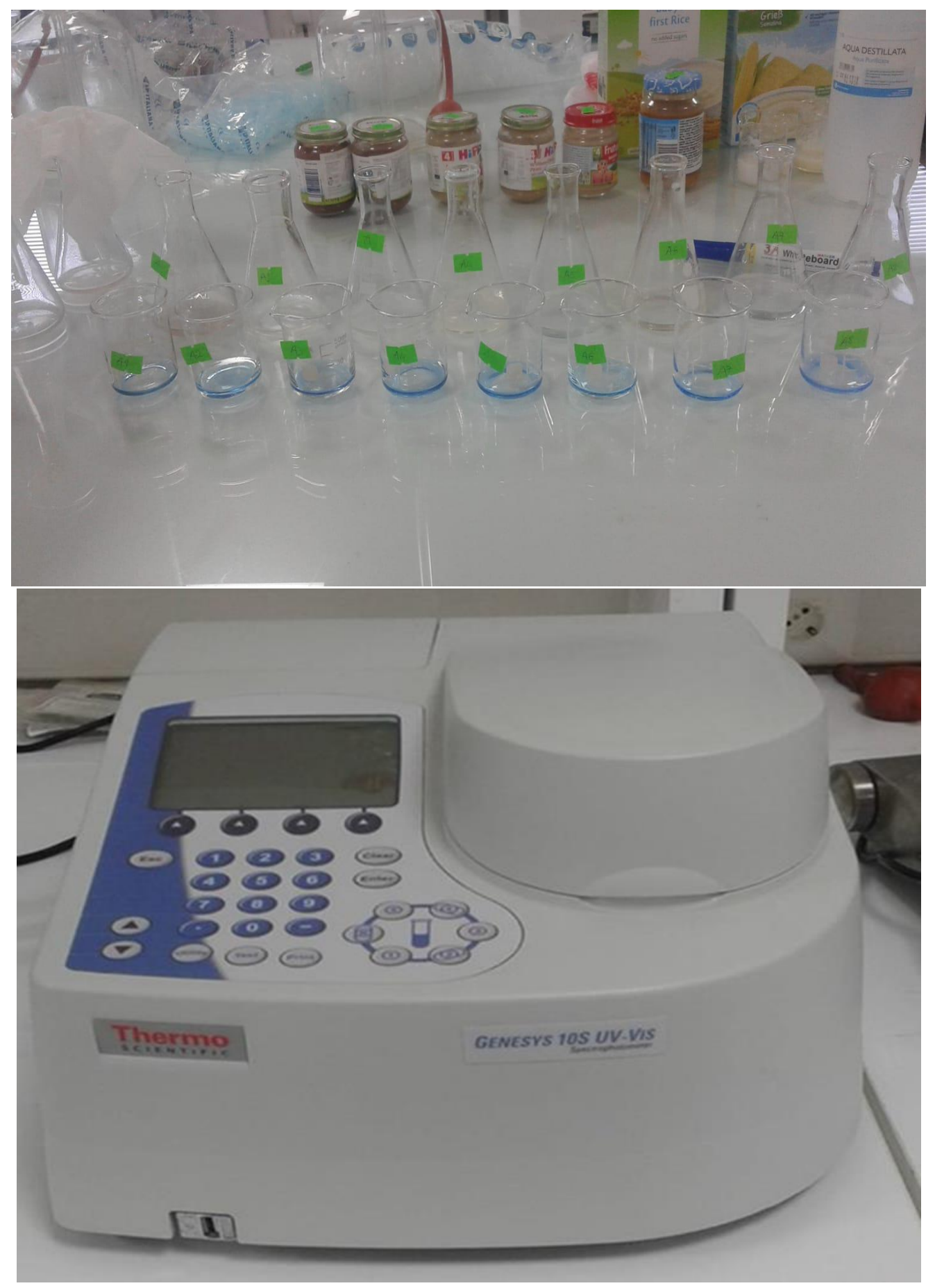

Figura 2. Përgaditja dhe analiza e mostrave 


\subsection{PËRCAKTIMI I PARAMETRAVE}

\subsubsection{PËRCAKTIMI I pH-së}

pH e mostrave është përcaktuar duke përdorur pH metër digjital.pH metri është kalibruar para matjeve duke përdorur tretësira puferike me $\mathrm{pH} 4$ dhe $7 . \mathrm{pH}$ matet direkt duke vendosur elektrodën e $\mathrm{pH}$ metrit në gotë laboratorike ku kemi vendosur paraprakisht $5 \mathrm{~mL}$ tretësirë të mostrës për analizë.

\subsubsection{PËRCAKTIMI I MATERIES SË THATË TË TRETSHME ('Brix)}

Materia e thatë e tretshëme u përcaktua duke përdorur refraktometrin Abbe në $20^{\circ} \mathrm{C}$ sipas metodës standarde (AOAC, 2016). Refraktometri është i lidhur me termometër për kontrollin e temperaturës, dhendizet burimi i dritës ndezur para përcaktimit. Refraktometri u pastrua me ujë të distiluar para se pikat e mostrave të vendoseshin në xhamin e refraktometrit dhe kapaku të mbyllej dhe lexohet materia e thatë e tretshme e mostrave në shkallë brix ( ${ }^{\circ}$ Brix).

\subsubsection{PËRCAKTIMI I LAGËSHTISË. METODA ME THARJE NË FURRË NË 105C}

Kjo metodë bazohet në tharjen e produktit të vendosur në furrë, në tempëraturë $105^{\circ} \mathrm{C}$ për 2 orë. Në fillim peshohen enët e thata pastaj vendosen mostrat dhe maten me mostra në peshore analitike dhe në fund pas tharjes maten në peshore analitike.

Lagështia llogaritet sipas ekuacionit :

$$
\% \text { lagështisë }=M_{1}-M_{2} / P \times 100
$$

$\mathbf{M}_{1}=$ Masa $(\mathrm{g})$ e enës me mostër para tharjes ;

$\mathbf{M}_{2}=$ Pesha $(\mathrm{g})$ e mostrës pas tharjes dhe

$\mathbf{P}=$ Masa e produktit.

\subsubsection{PËRCAKTIMI I ACIDITETIT}

Metoda për përcaktimin e aciditetit që e kemi përdor është titrimi i mostrës me $\mathrm{NaOH}$ me përqendrim $0,1 \mathrm{~mol} / \mathrm{dm}$ duke përdorur indikatorin fenolftaletin. Nga mostra ndahet $1 \mathrm{~g}$ të cilat treten në $10 \mathrm{ml}$ ujë të distiluar, titrohet me $\mathrm{NaOH}$ me $\mathrm{c}=0,1 \mathrm{~mol} / \mathrm{dm}$ deri në ndryshimin $\mathrm{e}$ ngjyrës.

Sasia e aciditetit në mostër e shprehur në përqindjen e acidit citrik llogaritet sipas ekuacionit:

\section{$\%$ Aciditeti $=\mathrm{C}_{(\mathrm{NaOH})} \times \mathrm{V}_{(\mathrm{NaOH})} \times M_{(\text {acid citrik })} /$ Masa e mostrës}

\subsubsection{PËRCAKTIMI I SHEQERËNAVE TOTALE}

Tek produktet me prejardhje bimore karbohidratet janë përbërësit kryësor. Sheqerënat të cilat janë në sasi më të madhe janë: glukozë, fruktozë, saharozë. Metodën të cilën e kemi përdor është me anë të acidit fenol acid sulfurik (Nielsen,2009). Glukoza është përdorur për ndërtimin e drejtzës kaliburese dhe matja e absorbancës është bërë në $490 \mathrm{~nm}$. 
Tretësirat standarde glukozës është përgaditur duke tretur 0,1 gram glukozë në $100 \mathrm{~cm}^{3}$ ujë të distiluar,pastaj është përgaditur seria standarde me 5 hollime duke filluar nga $1 \mathrm{~mL}, 3 \mathrm{~mL}, 5 \mathrm{~mL}, 7 \mathrm{~mL}, 9 \mathrm{~mL}$ dhe duke i tretur në enë normale $10 \mathrm{~mL}$ dhe nivelizuar me ujë të distiluar deri në shenjë.Reagjentët të cilët janë fenol dhe acid sulfurik të cilët shtohe në mostrat e filtruara dhe matet absorbanca.

Kurse, sasia e saharozës është përcaktuar duke kalkuluar diferencën mes sheqernave totale dhe sheqernave të reduktuara.

\subsubsection{PËRCAKTIMI I SHEQERNAVE TË REDUKTUARA}

Përcaktimi i sheqernave të reduktuar ëshë bërë me metodën Lan-Enjon si dhe tretësirat e Fehlingut të cilat janë të bazuara sipas standardit AOAC 2016.

Në erlenmajer vendoset $5 \mathrm{~mL}$ mostër e filtruar dhe e holluar me ujë të distiluar deri në $15 \mathrm{~mL}$. Shtojmë $15 \mathrm{~cm}^{3}$ të tretësirës nga bureta që përmban tretësirat standarde Fehling I dhe Fehling II dhe shënojmë ngjyrën e përzierjes. Vendoset erlenmajeri në një pllakë të nxehtë dhe përzierja vlonë jo më shumë se 2 minuta.Nëse ngjyra origjinale vazhdon pasi të vlojë për 10-15 sekonda, tregon se shumica e tretësirës Fehling nuk është zvogëluar ende dhe vazhdon titrimi deri në paraqitjen e ngjyër së portokallët.Shtojmë tre ose katër pika të indikatorit metilen blu dhe vazhdon titrimi, derisa ngjyra të ndryshojë nga blu në të njëjtën pamje të ndritshme portokalli që kishte përpara shtimit të indikatorit metilen blu. Nxehet tretësira në erlenmajer për 2 minuta. Shtojmë tre ose katër pika të indikatorit metilen blu dhe vazhdon titrimi derisa tretësira të bëhet e pangjyrë. Titrimi duhet të përfundojë brenda 3 minutave dhe gjatë kësaj kohe përzierja duhet të mbahet duke përzier vazhdimisht për të përjashtuar ajrin.

Sasia e sheqerënave të reduktuar llogaritet sipas ekuacionit:

$\%$ Sheqer i reduktuar $=$ Faktori i tretësirës Fehling $\times$ Vëllimi $\times 100 /$ Titrin $\times$ masa e mostrës $\times \mathrm{mL}$ tretësirës

\subsubsection{PËRCAKTIMI I VITAMINËS C}

Dredhëzat si fruta kanë përmbajtje të lartë të vitaminës C. Vitamina C është e tretshme në ujë dhe nuk sintetizohet nga organizmi dhe si e tillë duhet të merret me anë të ushqimit. Kjo vitaminë ëshrë shumë e rëndësishme për organizmin duke qenë një antioksidant i fuqishëm, mbron sistemin imunitar dhe ruan shëndetin e qelizave në trup. Vitamina $C$ gjendet në sasi të madhe tek dredhëzat dhe gjatë sezonës së kultivimit të tyre dredhëzat janë opsion i përshtatshëm i burimit të kësaj vitamine.

Metoda që kemi përdor për matjen e kesaj vitamine është spektofotometri UV-VIS duke matur përqëndimin dhe absorbancën e mostrave. Reagjenti i cili është përdorur është permanganati i kaliumit që në bashkëveprim me vitaminën $C$ jep një kompleks të tretshëm me ngjyrë vjollce intenzive dhe absorbanca e tretësirës matet në $530 \mathrm{~nm}$ pas qëndrimit 10 minuta.

Tretësirat standarde acidit askorbik është përgaditur duke tretur 0,1 gram acid askorbik në $100 \mathrm{~cm}^{3}$ ujë të distiluar,pastaj është përgaditur seria standarde me 5 hollime duke filluar nga 
$1 \mathrm{~mL}, 3 \mathrm{~mL}, 5 \mathrm{~mL}, 7 \mathrm{~mL}, 9 \mathrm{~mL}$ dhe duke i tretur në enë normale $10 \mathrm{~mL}$ dhe nivelizuar me ujë të distiluar deri në shenjë.Reagjenti i cili është përdorur është permanganati i kaliumit shtohet në mostrat e filtruara dhe matet absorbanca.

\subsubsection{PËRCAKTIMI I RAPORTIT SHEQER/ACID}

Raporti sheqer / acid kontribuon në dhënien e shumë frutave aromën e tyre karakteristike dhe është një tregues i pjekurisë tregtare dhe organoleptike. Në fillim të procesit të pjekjes, raporti sheqer / acid është i ulët, për shkak të përmbajtjes së ulët të sheqerit dhe përmbajtjes së lartë të acideve frutore, kjo e bën frutin me shije. Gjatë procesit të pjekjes acidet e frutave degradohen, përmbajtja e sheqerit rritet dhe raporti sheqer / acid arrinë vlerë më të lartë. Frutat tepër të pjekura kanë nivele shumë të ulëta të acidit frutor dhe për këtë arsye u mungon aroma karakteristike. Raporti sheqer/acid në mostër është përcaktuar duke llogaritur nga ekuacioni:

\section{Sheqer $/$ acid $=$ TSS $(\circ$ Brix $) / \%$ TA}

\subsubsection{PËRCAKTIMI I PROTEINAVE}

Tek dredhëzat, proteinat janë në sasi mjaft të vogël duke përfshi $0.3-0.7 \%$ totale.Metoda që është përdor për matje e proteinave është meoda Bredford me disa modifikime.Absorbanca matet në gjatësi valore $545 \mathrm{~nm}$ duke përdorur xhelatinën si tretësirë standarde.

Tretësirat standarde xhelatinë është përgaditur duke tretur 0,1 gram xhelatinë në $100 \mathrm{~cm}^{3}$ ujë të distiluar,pastaj është përgaditur seria standarde me 5 hollime duke filluar nga $1 \mathrm{~mL}, 3 \mathrm{~mL}, 5 \mathrm{~mL}, 7 \mathrm{~mL}, 9 \mathrm{~mL}$ dhe duke i tretur në enë normale $10 \mathrm{~mL}$ dhe nivelizuar me ujë të distiluar deri në shenjë.Reagjenti i cili është përdorur është reagjenti i Biuretit (Fehling 1 dhe Fehling 2) shtohet në mostrat e filtruara dhe matet absorbanca.

\subsubsection{PËRCAKTIMI I YNDYRAVE}

Tek dredhëzat gjendet sasi e vogël e yndyrave, që i bënë shumë të përshtatshme për konsum në dietat ushqimore. Metoda që është përdorur për ta ekstraktuar yndyrën është metoda e Solxhetit. Fillimisht, merren 5 gram mostër dhe vendosen në aparaturën solxhet dhe si tretës është përdorur petroleteri. Pas ekstraktimit sasia e yndyrës matet. 


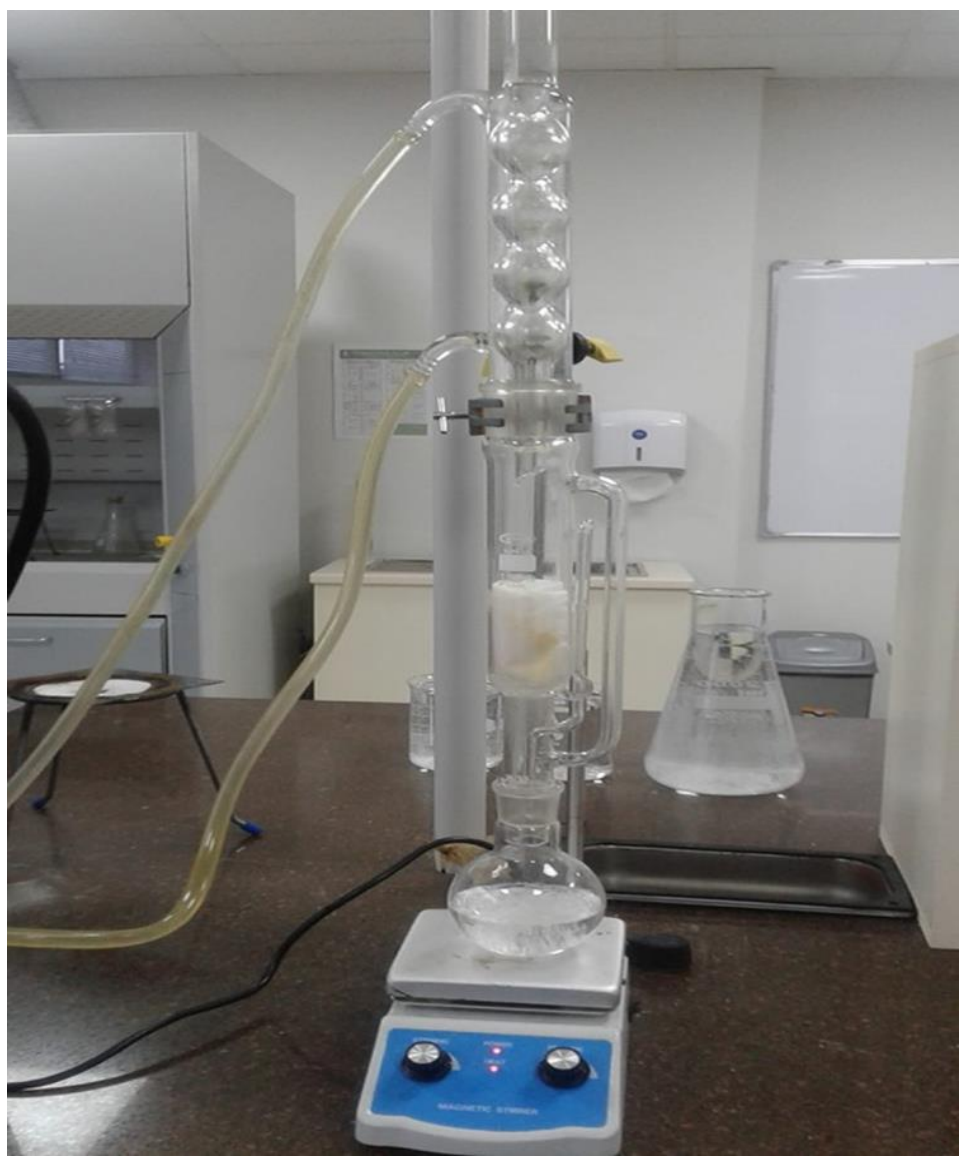

Figura 3. Ekstraktimi Solxhet i mostrave

\section{ANALIZAT STATISTIKORE}

Të gjitha të dhënat janë paraqitur si vlerë mesatare \pm dhe devijimi standard të eksperimenteve të trefishta. Të gjitha analizat statistikore janë përcaktuar me përdorimin e programit MS EXCEL dhe softwerit për statistika SPSS 22.0. Dallimet janë rishikuar për shkak të saktësisë duke përdorur metodën ANOVA, me nivel të saktësisë $\mathrm{p}<0.05$. 


\section{REZULTATET DHE DISKUTIMET}

Mostrat e ushqimeve komerciale për foshnja me bazë drithërat me emrin tregtar HUMANA (produkt me bazë misri) dhe HiPP (produkt me bazë orizi) janë blerë nga marketet dhe farmacitë në Kosovë gjatë periudhës Qershor 2019. Më poshtë janë të vendosura rezultatet eksperimentale në Tabelën 2 dhe 3 si dhe Figurën 4-7.

Tabela 2. Përberja kimike e ushqimit për foshnja dhe fëmijë me bazë drithërat

\begin{tabular}{|l|l|l|l|l|l|}
\hline Mostrat: & pH & W(DM)/\% & TSS/Brix & TA / \% & $\begin{array}{l}\text { Vitamin C } \\
\mathbf{m g} / \mathbf{1 0 0 g}\end{array}$ \\
\hline $\begin{array}{l}\text { A1 } \\
\text { HUMANA(produkt } \\
\text { me bazë misri }\end{array}$ & $6.78 \pm 0.1$ & $9.0 \pm 0.1$ & $5.1 \pm 0.1$ & $0.30 \pm 0.1$ & $40 \pm 0.2$ \\
\hline $\begin{array}{l}\text { A2 } \\
\text { HiPP(produkt me } \\
\text { bazë orizi }\end{array}$ & $6.95 \pm 0.1$ & $2.0 \pm 0.1$ & $11.1 \pm 0.1$ & $0.5 \pm 0.1$ & $02 \pm 0.1$ \\
\hline
\end{tabular}

Të dhënat janë paraqitur si vlera mesatare \pm të devijimit standard të tri mostrave

Tabela 3. Vlerat nutricionale të ushqimit për foshnja dhe fëmijë me bazë drithërat

\begin{tabular}{|l|l|l|l|l|l|l|}
\hline Mostrat: & $\begin{array}{l}\text { Sheqerna } \\
\mathbf{t} \text { totale } \\
\mathbf{g} / \mathbf{1 0 0 g}\end{array}$ & $\begin{array}{l}\text { Sheqernat } \\
\text { reduktues } \\
\text { e g/100g }\end{array}$ & $\begin{array}{l}\text { Saharoz } \\
\mathbf{a ~ g / 1 0 0 g}\end{array}$ & $\begin{array}{l}\text { Lipide } \\
\mathbf{t} \\
\mathbf{g} / \mathbf{1 0 0 g}\end{array}$ & $\begin{array}{l}\text { Proteina } \\
\mathbf{t} \\
\text { g/100g }\end{array}$ & $\begin{array}{l}\text { Energji } \\
\mathbf{a} \\
\text { kcal }\end{array}$ \\
\hline $\begin{array}{l}\text { A1 } \\
\text { HUMANA(produk } \\
\text { t } \\
\text { me bazë misri) }\end{array}$ & $68.0 \pm 0.1$ & $28.0 \pm 0.2$ & $30.0 \pm 0.2$ & $8.9 \pm 0.1$ & $13.6 \pm 0.1$ & 412 \\
\hline $\begin{array}{l}\text { A2 } \\
\text { HiPP(produkt me } \\
\text { bazë orizi) }\end{array}$ & $85.0 \pm 0.3$ & $3.22 \pm 0.1$ & $81.78 \pm 0$. & $0.7 \pm 0.2$ & $7.2 \pm 0.1$ & 379 \\
\hline
\end{tabular}

Të dhënat janë paraqitur si vlera mesatare \pm të devijimit standard të tri mostrave 
Vlerat e pH-së te ushqimet e foshnjeve dhe fëmijëve me bazë drithërat kanë tendencë të jenë më të ulta, duke filluar nga 6.78 \pm 0.1 te mostra $\mathrm{A}_{1}$ (HUMANA) dhe 6.95 \pm 0.1 te mostra $\mathrm{A}_{2}$ (HiPP). Vlerat e materiës së thatë te ushqimi per foshnja me baze drithërat varion nga $9.0 \pm 0.1 \%$ te mostra $\mathrm{A}_{1}$ (HUMANA) dhe shkon duke u zvogluar te mostra $\mathrm{A}_{2}(\mathrm{HiPP})$ në 2.0 $0.1 \%$. Materia e thatë e tretshme e matur me TSS/ ${ }^{\circ}$ Brix, përmbajtja e së cilës është $5.1 \pm 0.1 \circ$ Brix te mostra $\mathrm{A}_{1}$ (HUMANA) dhe shkon duke u rritur te mostra tjeter $\mathrm{A}_{2}(\mathrm{HiPP})$ në $11.1 \pm 0.1 \circ$ Brix. Aciditeti total te mostrat e ushqimit për foshnja dhe fëmijë ka rezultuar të jet me sasi më të ulëta nga $0.30 \pm 0.1$ te mostra $\mathrm{A}_{1}$ (HUMANA) dhe $0.22 \pm 0.1$ te mostra $\mathrm{A}_{2}(\mathrm{HiPP})$. Nga rezultatet eksperimentale të fituara, mostra $\mathrm{A}_{1}$ (HUMANA) është nje burim i mirë i vitaminës $\mathrm{C}$. Përmbajtja e vitaminës $C$ është $40 \pm 0.2 \mathrm{mg} / 100 \mathrm{~g}$ dhe ka një vlerë më të vogël te mostra tjeter $\mathrm{A}_{2}$ (HiPP) vetëm $0.2 \pm 0.1 \mathrm{mg} / 100 \mathrm{~g}$ vitamin C. Ushqimi për foshnja me bazë drithërat është burim i mirë i sheqerënave për nga përmbajtja e tyre. Numri i përgjithshëm i sheqernave në

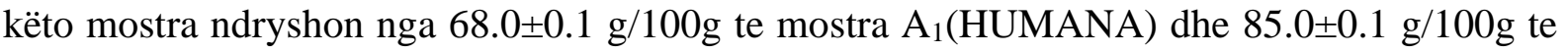
mostra $\mathrm{A}_{2}(\mathrm{HiPP})$. Nga këto vlera të sheqernave totale, sheqernat reduktuese variojnë nga $28.0 \pm 0.1 \mathrm{~g} / 100 \mathrm{~g}$ në mostren $\mathrm{A}_{1}($ HUMANA) dhe me vlera me te ulëta $3.22 \pm 0.1 \mathrm{~g} / 100 \mathrm{~g}$ te mostra $\mathrm{A}_{2}(\mathrm{HiPP})$. Vlerat e proteinave rezultuan midis $13.6 \pm 0.1 \mathrm{~g} / 100 \mathrm{~g}$ në mostren $\mathrm{A}_{1}(\mathrm{HUMANA})$ në $7.2 \pm 0.2 \mathrm{~g} / 100 \mathrm{~g}$ te mostra tjeter $\mathrm{A}_{2}$ (HiPP). Përmbajtja e lipideve është $8.9 \pm 0.1 \mathrm{~g} / 100 \mathrm{~g}$ në mostrën $A_{1}$ (HUMANA) dhe më e ulët në mostrën $A_{2}$ (HiPP) $0.70 \pm 0.2 \mathrm{~g} / 100 \mathrm{~g}$.

Rezultatet e fituara mund të jenë të dobishme në sqarimin e cilësisë së ushqimit per foshnja dhe fëmijë (te produktet me bazë drithërat). Këto mostra sic e kemi cekë jane blerë nga tregu dhe farmacitë e Kosovës gjate periudhës qershor 2019 dhe ishin të gjitha brenda kufijve të lejuar dhe të deklaruara në etiketë. Sidoqoftë, si masë paraprake, udhëzimet e ruajtjes dhe deklarimi në etiketat e produkteve duhet të ndiqen gjithmonë.

Mostrat e ushqimeve komerciale për foshnja me bazë fruta me emrin tregtar FRUTEK (Banane, produkt me bazë fruta),HiPP (Fruta mali në mollë, kumbull,mollë me banane, produkte me bazë fruta) dhe HELLO (Karrotë dhe mollë e gjelbërt, produkt me bazë fruta-perime) janë blerë në markete dhe farmaci në Kosovë gjatë periudhës Qershor 2019.

Më poshtë janë të vendosura rezultatet eksperimentale në Tabelën 4 dhe 5 si dhe Figurën 4-7. 
Tabela 4. Përberja kimike e ushqimit për foshnja dhe fëmijë me bazë fruta

\begin{tabular}{|c|c|c|c|c|c|}
\hline Mostrat: & pH & $\mathrm{W}(\mathrm{DM}) / \%$ & TSS $/ \circ$ Brix & TA / \% & $\begin{array}{l}\text { Vitamin C } \\
\mathrm{mg} / 100 \mathrm{~g}\end{array}$ \\
\hline $\begin{array}{l}\text { A3 } \\
\text { Hipp (Mollë dhe } \\
\text { fruta mali) }\end{array}$ & $3.94 \pm 0.1$ & $1.34 \pm 0.1$ & $7.0 \pm 0.1$ & $0.61 \pm 0.2$ & $30 \pm 0.2$ \\
\hline $\begin{array}{l}\text { A4 } \\
\text { HiPP (kumbull) }\end{array}$ & $3.55 \pm 0.1$ & $3.35 \pm 0.1$ & $6.2 \pm 0.1$ & $0.55 \pm 0.2$ & $30 \pm 0.2$ \\
\hline $\begin{array}{l}\mathbf{A 5} \\
\text { HiPP (Mollë me } \\
\text { banane) }\end{array}$ & $3.98 \pm 0.1$ & $2.24 \pm 0.1$ & $5.0 \pm 0.1$ & $0.58 \pm 0.2$ & $8.9 \pm 0.2$ \\
\hline $\begin{array}{l}\text { A6 } \\
\text { HiPP (Dardhë) }\end{array}$ & $3.88 \pm 0.1$ & $2.43 \pm 0.1$ & $4.75 \pm 0.1$ & $0.48 \pm 0.2$ & $10 \pm 0.2$ \\
\hline $\begin{array}{l}\text { A7 } \\
\text { FRUTEK(Banane) }\end{array}$ & $4.31 \pm 0.1$ & $2.61 \pm 0.1$ & $5.1 \pm 0.1$ & $0.35 \pm 0.2$ & $8.7 \pm 0.2$ \\
\hline $\begin{array}{l}\text { A8 } \\
\text { HELLO (Karrotë } \\
\text { dhe mollë) }\end{array}$ & $3.93 \pm 0.1$ & $2.13 \pm 0.1$ & $6.1 \pm 0.1$ & $0.30 \pm 0.2$ & $10 \pm 0.2$ \\
\hline
\end{tabular}

Të dhënat janë paraqitur si vlera mesatare \pm të devijimit standard të tri mostrave

Tabela 5. Vlerat nutricionale të ushqimit për foshnja dhe fëmijë me bazë fruta

\begin{tabular}{|l|l|l|l|l|l|l|}
\hline Mostrat: & $\begin{array}{l}\text { Sheqerna } \\
\mathbf{t} \text { totale } \\
\mathbf{g} / \mathbf{1 0 0 g}\end{array}$ & $\begin{array}{l}\text { Sheqernat } \\
\text { reduktues } \\
\mathbf{e} \mathbf{g} / \mathbf{1 0 0 g}\end{array}$ & $\begin{array}{l}\text { Saharoz } \\
\mathbf{a ~ g / 1 0 0 g}\end{array}$ & $\begin{array}{l}\text { Lipidet } \\
\mathbf{g} / \mathbf{1 0 0 g}\end{array}$ & $\begin{array}{l}\text { Proteina } \\
\mathbf{t} \\
\mathbf{g} / \mathbf{1 0 0 g}\end{array}$ & $\begin{array}{l}\text { Energii } \\
\mathbf{a} \\
\text { kcal }\end{array}$ \\
\hline $\begin{array}{l}\text { A3 } \\
\text { Hipp (Mollë dhe } \\
\text { fruta mali) }\end{array}$ & $12.4 \pm 0.1$ & $9.2 \pm 0.1$ & $3.2 \pm 0.1$ & $0.1 \pm 0.01$ & $0.5 \pm 0.1$ & 55 \\
\hline $\begin{array}{l}\text { A4 } \\
\text { HiPP (kumbull) }\end{array}$ & $16.0 \pm 0.1$ & $11.2 \pm 0.1$ & $4.8 \pm 0.1$ & $0.1 \pm 0.01$ & $0.5 \pm 0.1$ & 69 \\
\hline A5 & $13.2 \pm 0.1$ & $12.1 \pm 0.1$ & $1.1 \pm 0.1$ & $0.1 \pm 0.01$ & $0.5 \pm 0.1$ & 59 \\
\hline
\end{tabular}




\begin{tabular}{|l|l|l|l|l|l|l|}
\hline $\begin{array}{l}\text { HiPP (Mollë me } \\
\text { banane) }\end{array}$ & & & & & & \\
\hline $\begin{array}{l}\text { A6 } \\
\text { HiPP (Dardhë) }\end{array}$ & $11.0 \pm 0.1$ & $9.1 \pm 0.1$ & $1.9 \pm 0.1$ & $0.3 \pm 0.01$ & $0.5 \pm 0.1$ & 55 \\
\hline $\begin{array}{l}\text { A7 } \\
\text { FRUTEK(Banane } \\
)\end{array}$ & $15.8 \pm 0.1$ & $9.9 \pm 0.2$ & $5.9 \pm 0.1$ & $0.04 \pm 0.0$ & $0.8 \pm 0.1$ & 63.4 \\
\hline $\begin{array}{l}\text { A8 } \\
\text { HELLO (Karrotë } \\
\text { dhe mollë) }\end{array}$ & $18.9 \pm 0.1$ & $15.0 \pm 0.2$ & $3.9 \pm 0.2$ & $0.1 \pm 0.01$ & $0.1 \pm 0.01$ & 77 \\
\hline
\end{tabular}

Të dhënat janë paraqitur si vlera mesatare \pm të devijimit standard të tri mostrave

Vlerat e pH-së te ushqimet e foshnjeve dhe fëmijëve me bazë frutat kanë tendencë të jenë më

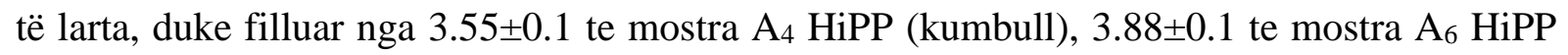
(dardhë), 3.93 \pm 0.1 te mostra $\mathrm{A}_{8}$ HELLO (Karrotë dhe mollë), 3.94 \pm 0.1 te mostra $\mathrm{A}_{3} \mathrm{HiPP}$ (Mollë dhe fruta mali), 3.98 \pm 0.1 te mostra $\mathrm{A}_{5} \mathrm{HiPP}$ (Mollë dhe banane) dhe më e lartë 4.31 \pm 0.1 te mostra $\mathrm{A}_{7}$ FRUTEK (Banane).

Vlerat e materies së thatë te ushqimi per foshnja me bazë frutat varion nga $1.34 \pm 0.1$ te mostra $\mathrm{A}_{3} \mathrm{HiPP}$ (Mollë dhe fruta mali) dhe shkon duke u rritur te mostrat tjera si: $2.13 \pm 0.1$ te mostra $\mathrm{A}_{8}$ HELLO (Karrotë dhe mollë), 2.24 \pm 0.1 te mostra $\mathrm{A}_{5}$ HiPP (Mollë dhe banane), $2.43 \pm 0.1$ te mostra $\mathrm{A}_{6} \mathrm{HiPP}$ (dardhë), 4.31 \pm 0.1 te mostra $\mathrm{A}_{7}$ FRUTEK (Banane) dhe më e larta te $3.35 \pm 0.1$ mostra $\mathrm{A}_{4} \mathrm{HiPP}$ (kumbull).

Materia e thatë e tretshme e shprehur në shkallën Brix (TSS/॰Brix), përmbajtja e së cilës është 4.75 \pm 0.1 te mostra $\mathrm{A}_{6} \mathrm{HiPP}$ (dardhë), dhe shkon duke u rritur te mostrat tjera si: $5.0 \pm 0.1$ te

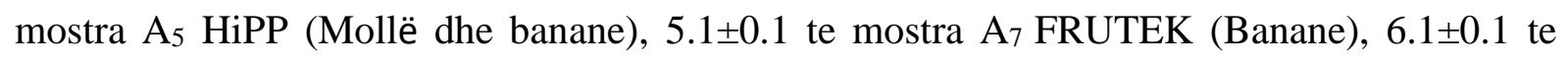
mostra $A_{8}$ HELLO (Karrotë dhe mollë), 6.2 \pm 0.1 mostra $\mathrm{A}_{4} \mathrm{HiPP}$ (kumbull) dhe më e larta 7.0 \pm 0.1 te mostra $\mathrm{A}_{3} \mathrm{HiPP}$ (Mollë dhe fruta mali).

Mostrat e ushqimit për foshnja dhe fëmijë rezultojnë me aciditet total jo shumë të lartë e shpreshur në \% të acidit citrik dhe kanë vlerat më të ulta te mostra te mostra $A_{8}$ HELLO (Karrotë dhe mollë) $0.30 \pm 0.2$ ndërsa vlerat më të larta të aciditetit total janë te mostra $\mathrm{A}_{3} \mathrm{HiPP}$ (Mollë dhe fruta mali) 0.61 \pm 0.2 .

Mostrat e ushqimit për foshnja dhe fëmijë janë burim i mirë i vitaminës C. Disa nga mostrat janë edhe të pasuruara me Vitamin $C$ dhe përmbajnë sasi të lartë të Vitaminës $C$ si mostrat $A_{3}$ HiPP (Mollë dhe fruta mali) 30 $\pm 0.2 \mathrm{mg} / 100 \mathrm{~g}$ poashtu edhe mostra A4 HiPP (kumbull) $30 \pm 0.2$ mg/100g. Sasi relatisht të lartë të Vitaminës C përmbajnë edhe mostrat: $\mathrm{A}_{6}$ HiPP (dardhë) $10 \pm 0.2 \mathrm{mg} / 100 \mathrm{~g}$ si dhe mostra $\mathrm{A}_{8}$ HELLO (Karrotë dhe mollë) $10 \pm 0.2 \mathrm{mg} / 100 \mathrm{~g}$, ndërsa 
mostrat $\mathrm{A}_{5} \mathrm{HiPP}$ (Mollë dhe banana) vlerat e Vitaminës $\mathrm{C}$ janë më të ulëta $8.9 \pm 0.2 \mathrm{mg} / 100 \mathrm{~g}$ dhe më të ulëta te mostra $A_{7}$ FRUTEK (Banane) $8.7 \pm 0.2 \mathrm{mg} / 100 \mathrm{~g}$.

Poashtu ushqimi për foshnja dhe fëmijë me bazë frutat është burim i mirë i sheqerënave dhe si rrjedhojë e saj janë burim i mirë i energjisë. Numri i përgjithshëm i sheqernave në këto mostra ndryshon nga $11.1 \pm 0.1 \mathrm{~g} / 100 \mathrm{~g}$ te mostra $\mathrm{A}_{6} \mathrm{HiPP}$ (dardhë), $12.4 \pm 0.1 \mathrm{~g} / 100 \mathrm{~g}$ te mostra $\mathrm{A}_{3} \mathrm{HiPP}$ (Mollë dhe fruta mali), $13.2 \pm 0.1 \mathrm{~g} / 100 \mathrm{~g}$ te mostra $\mathrm{A}_{5}$ HiPP (Mollë dhe banana), 15.8 \pm 0.1 $\mathrm{g} / 100 \mathrm{~g}$ te mostra $\mathrm{A}_{7}$ FRUTEK (Banane), $16.0 \pm 0.1 \mathrm{~g} / 100 \mathrm{~g}$ te mostra $\mathrm{A}_{4} \mathrm{HiPP}$ (kumbull) si dhe më e lartë te mostra $A_{8}$ HELLO (Karrotë dhe mollë) $18.9 \pm 0.1 \mathrm{~g} / 100 \mathrm{~g}$.

Nga këto vlera të sheqerënave totale, sheqerënat e reduktuara (galaktoza, glukoza, fruktoza, riboza etj.) variuan nga 9.1 $\pm 0.1 \mathrm{~g} / 100 \mathrm{~g}$ te mostra $\mathrm{A}_{6} \mathrm{HiPP}$ (dardhë), 9.2 $\pm 0.1 \mathrm{~g} / 100 \mathrm{~g}$ te mostra $\mathrm{A}_{3}$ HiPP (Mollë dhe fruta mali), 12.1 $\pm 0.1 \mathrm{~g} / 100 \mathrm{~g}$ te mostra $\mathrm{A}_{5}$ HiPP (Mollë dhe banana), $9.9 \pm 0.1 \mathrm{~g} / 100 \mathrm{~g}$ te mostra $\mathrm{A}_{7}$ FRUTEK (Banane), $11.2 \pm 0.1 \mathrm{~g} / 100 \mathrm{~g}$ te mostra $\mathrm{A}_{4} \mathrm{HiPP}$ (kumbull) si dhe më e lartë te mostra $A_{8}$ HELLO (Karrotë dhe mollë) $15.0 \pm 0.1 \mathrm{~g} / 100 \mathrm{~g}$. Rezultatet e saharozës janë fituar me llogaritje : sheqerëna totale -sheqerëna të reduktuara,vlerat e saharozës në krahasim me sheqerënat totale dhe të reduktuara janë më të vogla,si rrjedhojë sasia e saharozës është më e ultë.Vlerat e saharozës janë: $1.9 \pm 0.1 \mathrm{~g} / 100 \mathrm{~g}$ te mostra $\mathrm{A}_{6} \mathrm{HiPP}$ (dardhë), $3.2 \pm 0.1 \mathrm{~g} / 100 \mathrm{~g}$ te mostra $\mathrm{A}_{3} \mathrm{HiPP}$ (Mollë dhe fruta mali), $1.1 \pm 0.1 \mathrm{~g} / 100 \mathrm{~g}$ te mostra $\mathrm{A}_{5} \mathrm{HiPP}$ (Mollë dhe banana), 5.9 $\pm 0.1 \mathrm{~g} / 100 \mathrm{~g}$ te mostra $\mathrm{A}_{7}$ FRUTEK (Banane), $4.8 \pm 0.1 \mathrm{~g} / 100 \mathrm{~g}$ te mostra $\mathrm{A}_{4} \mathrm{HiPP}$ (kumbull) si dhe më e lartë te mostra $\mathrm{A}_{8}$ HELLO (Karrotë dhe mollë) $3.9 \pm 0.1 \mathrm{~g} / 100 \mathrm{~g}$. Vlerat e proteinave te ushqimi për foshnje dhe fëmijë me bazë frutat janë të ulta,ushqimet me bazë frutat nuk llogariten si ushqime proteinike dhe variojnë midis $0.5 \pm 0.1 \mathrm{~g} / 100 \mathrm{~g}$ te mostra $\mathrm{A}_{6} \mathrm{HiPP}$ (dardhë), 0.5 $\pm 0.1 \mathrm{~g} / 100 \mathrm{~g}$ te mostra $\mathrm{A}_{3} \mathrm{HiPP}$ (Mollë dhe fruta mali), $0.5 \pm 0.1 \mathrm{~g} / 100 \mathrm{~g}$ te mostra $\mathrm{A}_{5}$ HiPP (Mollë dhe banana), $0.5 \pm 0.1 \mathrm{~g} / 100 \mathrm{~g}$ te mostra $\mathrm{A}_{4} \mathrm{HiPP}$ (kumbull) si dhe më e ulta te mostra $A_{8}$ HELLO (Karrotë dhe mollë) $0.1 \pm 0.1 \mathrm{~g} / 100 \mathrm{~g}$ ndërsa më e larta $0.8 \pm 0.1 \mathrm{~g} / 100 \mathrm{~g}$ te mostra $\mathrm{A}_{7}$ FRUTEK (Banane).

Poashtu ushqimet për foshnje dhe fëmijë nuk janë ushqime të pasura me yndyrë. Përmbajtja e lipideve është e vogël dhe varion nga 0.04 $0.01 \mathrm{~g} / 100 \mathrm{~g}$ te mostra $\mathrm{A}_{7}$ FRUTEK (Banane),ndërsa te mostrat tjera vlera e saj është $0.1 \pm 0.01 \mathrm{~g} / 100 \mathrm{~g}\left(\mathrm{~A}_{3} \mathrm{HiPP}\right.$ (Mollë dhe fruta mali), $\mathrm{A}_{4} \mathrm{HiPP}$ (kumbull), A 5 HiPP (Mollë dhe banana), $\mathrm{A}_{8}$ HELLO (Karrotë dhe mollë),ndërsa vlera më e lartë është te mostra $\mathrm{A}_{6} \mathrm{HiPP}$ (dardhë) $0.3 \pm 0.01 \mathrm{~g} / 100 \mathrm{~g}$.

Përmbajtja e energjisë në mostrat e ushqimit për foshnja dhe fëmijë u përcaktua duke llogaritur sasinë e proteinave, yndyrës dhe karbohidrateve të mostrave përkatëse dhe duke përdorur ekuacionin e mëposhtëm.

\section{Energy $=($ Protein $\times 4.1)+($ Fat $\times 9.3)+($ Carbohydrate $\times 4.1)$}

Rezultatet e fituara mund të jenë të dobishme në sqarimin e cilësisë së ushqimit per foshnja dhe fëmijë (te produktet me bazë frutat). Këto mostra sic e kemi cekë jane blerë nga tregu dhe farmacitë e Kosovës gjate periudhës qershor 2019 dhe ishin të gjitha brenda kufijve të lejuar dhe të deklaruara në etiketë. Sidoqoftë, si masë paraprake, udhëzimet e ruajtjes dhe deklarimi në etiketat e produkteve duhet të ndiqen gjithmonë. 


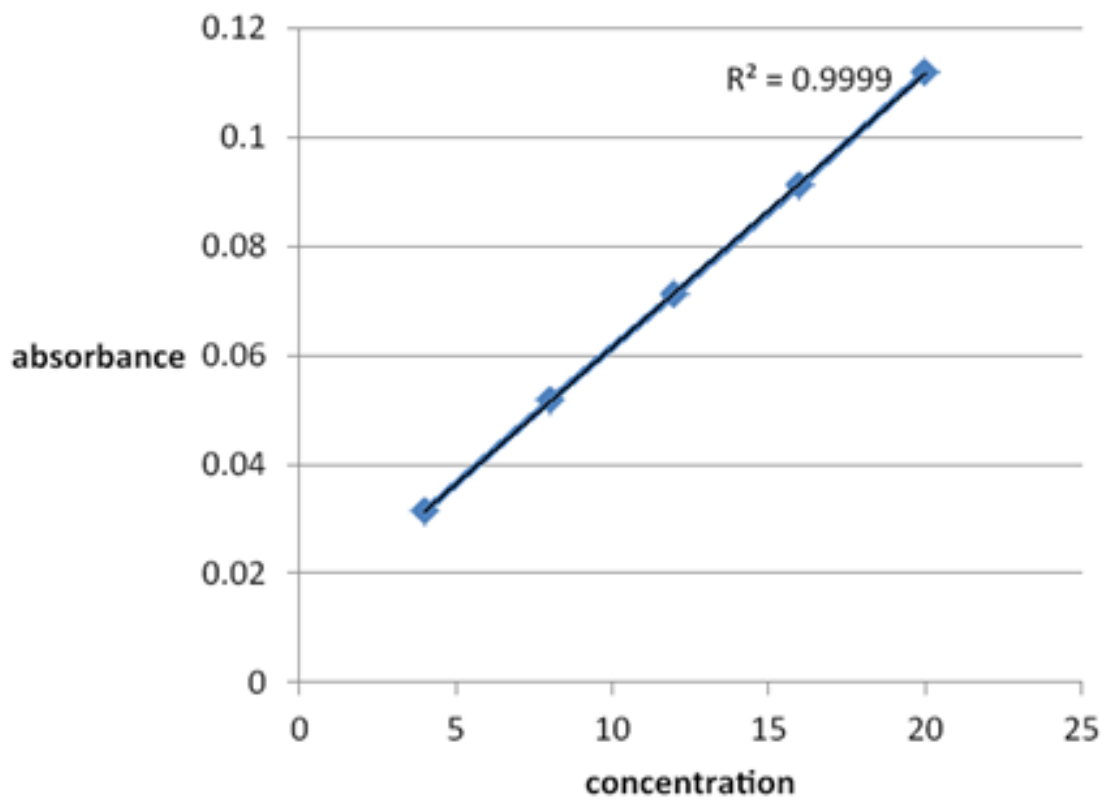

Figura 4. Drejtëza kalibruese e acidit askorbik (vitamina C)

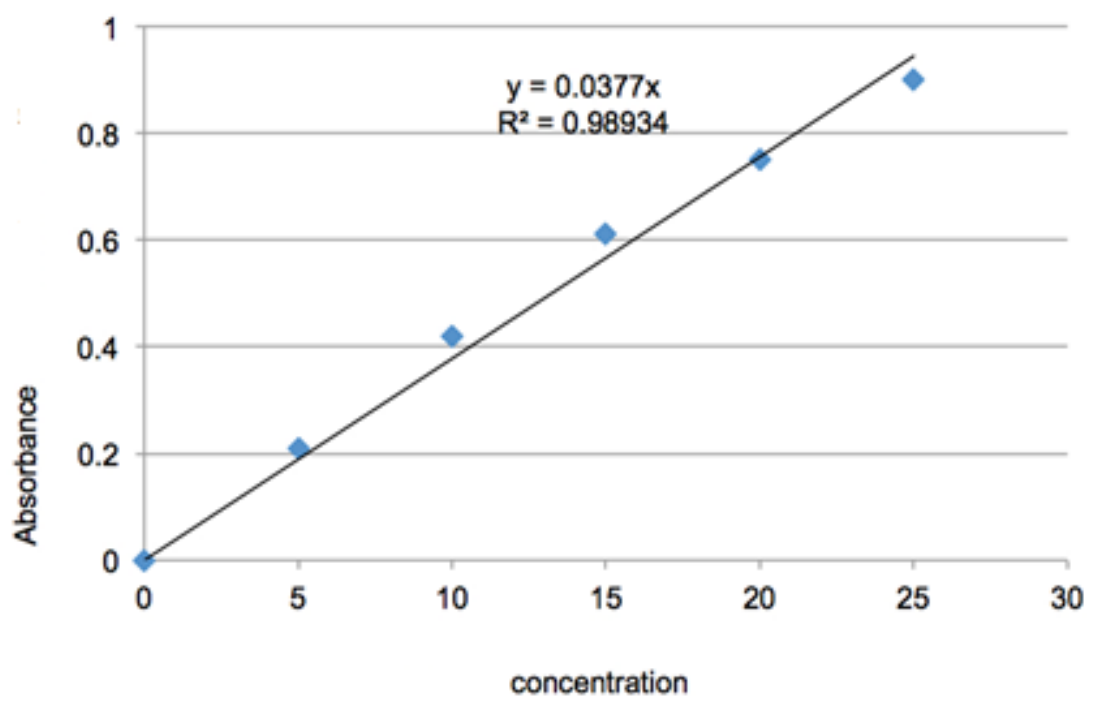

Figura 5. Drejtëza kalibruese e proteinës (xhelatinë) 


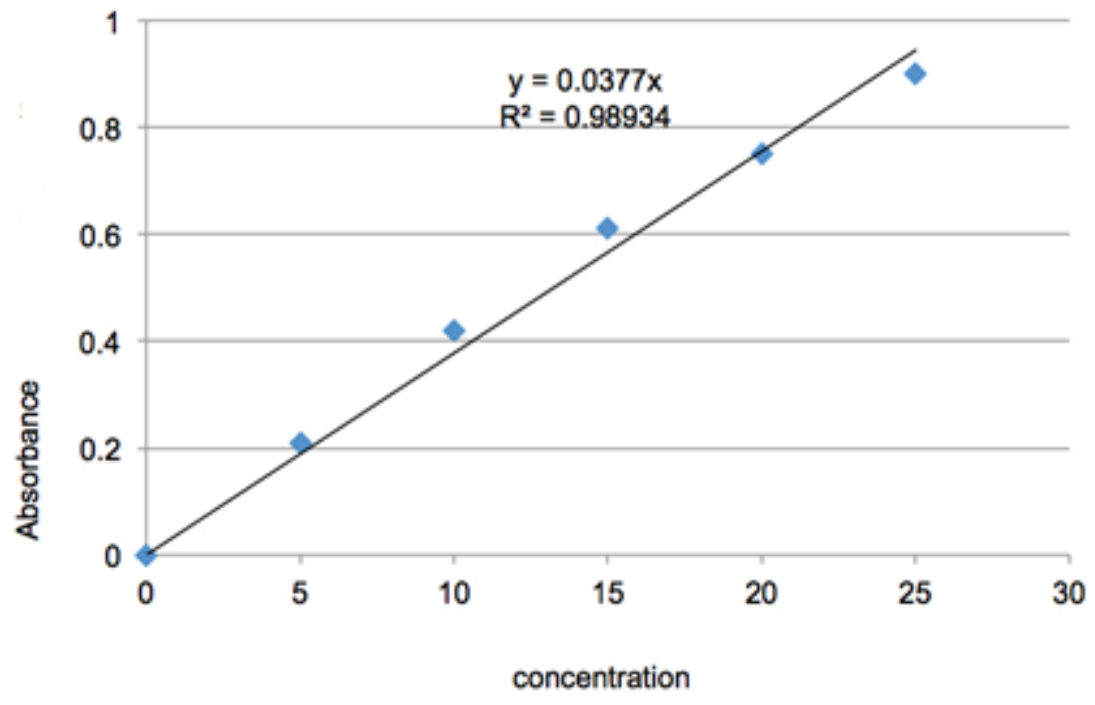

Figura 4. Drejtëza kalibruese e acidit askorbik (vitamina C)

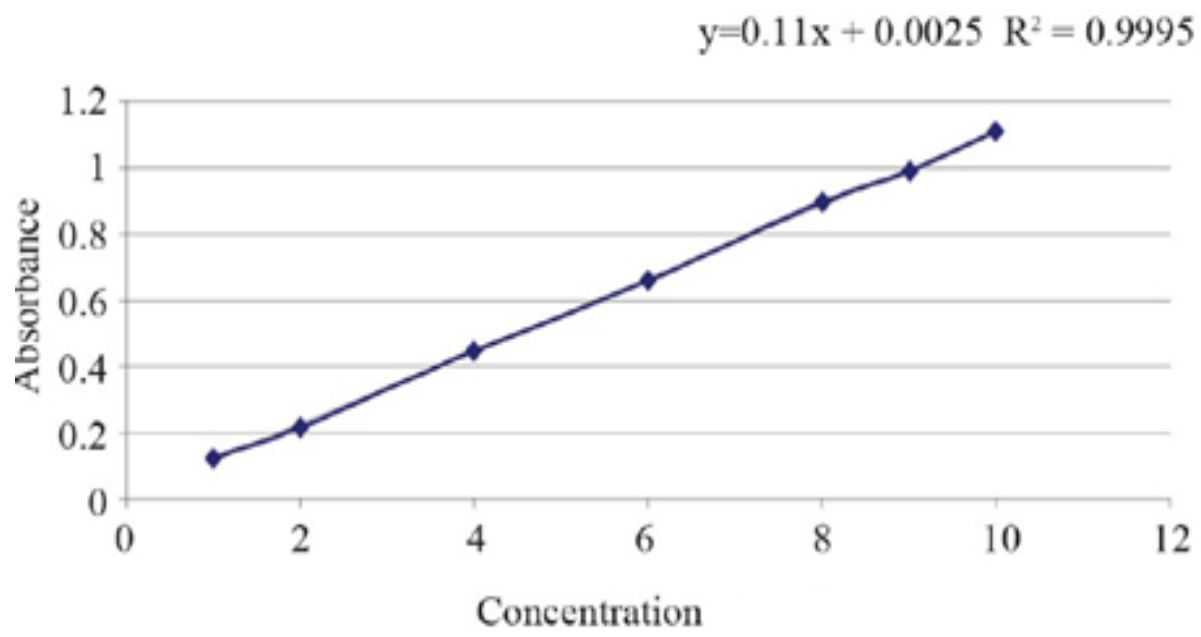

Figura 6.Drejtëza kalibruese e sheqerit (glukozë) 


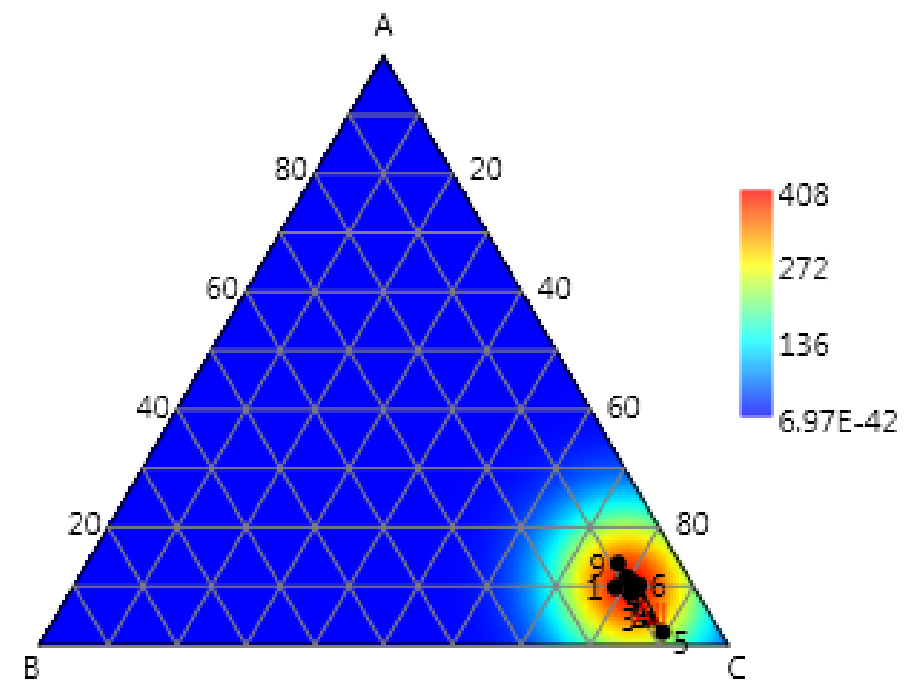

Figura 7. Vizualizimi 3D i të dhënave nga parametrat kimik dhe nutricional të ushqimeve për foshnja dhe fëmijë 


\section{KONKLUZIONET}

Ushqimet plotësuese për foshnja dhe fëmijë janë një gamë e gjerë e produkteve dhe përdorimi i tyre po rritet çdo ditë.Mostrat e ushqimit plotsues komercial për foshnje dhe fëmijë me bazë drithëra dhe me bazë fruta me emrin tregtar HUMANA (produkt me bazë misri), HiPP (produkt me bazë orizi),FRUTEK (Banane, produkt me bazë fruta),HiPP (Fruta mali në mollë, kumbull,mollë me banane, produkte me bazë fruta) dhe HELLO (Karrotë dhe mollë e gjelbërt, produkt me bazë fruta-perime) janë blerë në markete dhe barnatore në Kosovë gjatë periudhës qershor 2019. Të gjitha parametrat e përcaktuar (kimik dhe ushqyes) janë brenda kufijve të lejuar dhe të deklaruar në tiketë. Sidoqoftë, si një masë paraprake, udhëzimet dhe vërejtjet për deklarimin në etiketat e produkteve duhet të ndiqen gjithmonë. Të gjitha mostrat e ushqimit plotsues për foshnja dhe fëmijë prodhohen nga kompani të huaja pasi aktualisht Kosova nuk ka prodhues që prodhojnë këtë gamë të produkteve. Ky është hulumtimi i parë i këtij lloji në Kosovë dhe duhet të na japë një rezultat të ri. Edukimi i të ushqyerit për nënat dhe punonjësit shëndetësor në kopshtin e fëmijëve për zgjedhjen dhe përgatitjen e llojit të duhur të ushqimeve për foshnja dhe fëmijë dhe praktikat e pastrimit duhet të shkojnë shumë më përpara në përmirësimin e statusit ushqyes të foshnjave dhe fëmijëve në vend. 


\section{REFERENCAT}

[1] Abdulaziz M., Al-Othman M., Akmal K., Al-Kanhal M.A. (1997) Nutritional evaluation of some commercial baby foods consumed in Saudi Arabia.International Journal of food Sciences and Nutrition 48,229-236.

[2] Afriola Ceta (Mema)."Studimi i ekuilibrave vitaminikë tek konsumatorët e zakonshëm dhe përdoruesit e preparative vitamikë apo suplementëve të pasur me to". Disertacion i doktoratës. Tiranë 2017.

[3] AOAC (2016). Official method of analysis. Maryland, USA: Publication by AOAC International.

[4] Calabretti A., Calabrese M., Campisi B., Bogoni P. (2017). Quality and Safety in Commercial Baby Foods. Journal of Food and Nutrition Research, 5,8.

[5] Ceta A., Troja R., Muca E., Shima O. (2017). Evalution of physic chemical parameters of baby food products. Interdisplinary Journal of Research and Development Vol (IV), No.2.

[6] Čížková H., Ševčík R., Rajchl A., Voldřich M.(2009). Nutritional Quality of Commercial Fruit Baby Food. Czech J. Food Sci. Vol. 27 Special Issue.

[7] Diallo M., Cissé M., Dessor F., Soulimani R., Sock O., Desobry S. (2013). Formulation of Infant Food Based on Local Cereals: Stability and Effects on Cognitive Development. Journal of Nutrition \& Food Sciences.3;4.

[8] Food and Agricultural Organization of the United Nations and the World Health Organization.CODEX STAN 074 - 1981, Rev. 1 - 2006.Codex standard for processed cerealbased foods for infants and young children [Internet]. Rome (Italy): Food and Agriculture Organization of the United Nations.

[9] García L.A., Raza S., Parrett A., Wright M.C.(2013). Nutritional content of infant commercial weaning foods in the UK .Arch Dis Child 8:793-797.

[10] Khamoni A.J., Hamshaw T., Gardiner H.E.P. (2017).Impact of ingredients on the elemental content of baby foods. Food chemistry, 231,309-315.

[11] Klerks M., Bernal J.M., Roman S., Bodenstab S., Gil A., Sanchez-Siles M.L. (2019). Infant Cereals: Current Status, Challenges, and Future Opportunities for Whole Grains. Nutrients 11473. 
[12] Klodiola Dhamo (2014). "Vlerësimi mikrobiologjik i ushqimeve për foshnje". Disertacion i doktoratës.Tirane 2014.

[13] Maalouf J., Cogswell E.M., Bates M., Yuan K., Scanlon S.K., Pehrsson P., Gunn P.J.,5 Merritt K.R.(2017). Sodium, sugar, and fat content of complementary infant and toddler foods sold in the United States, 2015 American Journal of Clinical Nutrition ;105:1443-52. [14] Nielsen S.S.(2009)Phenol-Sulfuric Acid Method for Total Carbohydrates. Food Analysis Laboratory Manual 47-53.

[15] Seidel K., Kahl J., Paoletti F., Birlouez I., Busscher N.,Kretzschmar U., SärkkäTirkkonen M., Randi Seljåsen R.,Sinesio F., Torp T., Baiamonte I. (2013). Quality assessment of baby food made of different pre-processed organic raw materials under industrial processing conditions. Journal of Food Science and Technology. DOI 10.1007/s13197-013$1109-5$

[16] Walker W.R. Goran I.M. (2015). Laboratory Determined Sugar Content and Composition of Commercial Infant Formulas, Baby Foods and Common Grocery Items Targeted to Children Nutrients, 7, 5850-5867.

[17] Zein H., Bhnsawy R.M. El-S., Arafa A.S. (2019). Nutritional Evaluation of Some Prepared Baby's Complementary Food Mixtures for Weaning Period World Journal of Dairy \& Food Sciences 14 (1): 79-86. 